\title{
TINGKAT PENGETAHUAN DAN SIKAP ORANGTUA BERHUBUNGAN DENGAN PENGGUNAAN OBAT TRADISIONAL PADA ANAK
}

\author{
Johanna Natasha Agaatsz*, Monalisa Sitompul \\ Fakultas Ilmu Keperawatan, Universitas Advent Indonesia, Jl. Kolonel Masturi No.288, Cihanjuang \\ Rahayu, Kec. Parongpong, Kabupaten Bandung Barat, Jawa Barat 40559, Indonesia \\ *jnatashaa20@gmail.com (+6282127297959)
}

\begin{abstract}
ABSTRAK
Orangtua sangatlah memiliki peran penting dalam sebuah keluarga, khususnya bagi anak dan orangtua juga sangat berpengaruh dalam mengambil keputusan terumata untuk anak mereka, penelitian ini dilakukan karena untuk melihat pentingnya peran orangtua saat anak sakit dan untuk melihat apakah tindakan orangtua sudah tepat dalam mengobati anak mereka yang sakit dengan menggunakan pengobatan tradisional yang mereka lakukan sendiri,dan diharapkan setelah adanya penelitian ini akan meningkatkan kualitas orangtua serta pengetahuan orangtua dan sikap yang dimiliki orangtua dalam penggunaan obat tradisional. Tujuan penelitian ini ialah untuk mengetahui apakah ada hubungan yang signifikan dari tingkat pengetahuan serta sikap orangtua yang berada di desa karegesan dalam menggunakan obat tradisional untuk pengobatan pada anak. Metode penelitian ini adalah deskriptif korelasi, teknik pengambilan sampel secara purposive sampling dengan total 52 responden. Penelitian ini dilakukan secara online, yaitu peneliti mengirimkan kuesioner dalam bentuk googleform kepada responden melalui aplikasi whatsapp. analisa data menggunakan uji korelasi pearson correlation dengan hasil Adanya hubungan yang signifikan dari pengetahuan yang kurang baik dengan sikap orangtua yang kurang baik dalam menggunakan obat tradisional untuk pengobatan pada anak dengan $p$ value $0,000<0,05$.
\end{abstract}

Kata kunci: anak; orangtua; pengetahuan; pengobatan; sikap

\section{KNOWLEDGE AND ATTITUDES OF PARENTS RELATED TO THE USE OF TRADITIONAL DRUGS IN CHILDREN}

\begin{abstract}
Parents have a very important role in a family, especially for children. And parents are also very influential in making the most common decisions for their children, this research was conducted because it was to see the importance of the role of parents when a child was sick and to see whether the parents' actions were appropriate in treating their child who are sick by using traditional medicine that they do themselves, and it is hoped that after this research will improve the quality of parents as well as parental knowledge and attitudes that parents have in the use of traditional medicine. The purpose of this study was to determine whether there is a significant relationship between the level of knowledge and attitudes of parents in the Karegesan village in using traditional medicine for the treatment of children. This research method is descriptive correlation, the sampling technique is purposive sampling with a total of 52 respondents. This research was conducted online, in which the researcher sent a questionnaire in the form of google form to respondents via the WhatsApp application. Data analysis using the Pearson correlation test with the results. There is a significant relationship between poor knowledge and poor parental attitudes in using of traditional medicines for treatment in children with a $p$ value of $0.000<0.05$.
\end{abstract}

Keywords: attitude; child; knowledge; parents; treatment 


\section{PENDAHULUAN}

Penggunaan obat tradisional tentunya sudah tidak asing lagi dikalangan masyarakat Indonesia, khususnya bagi warga yang tempat tinggalnya masih jauh dari pelayanan kesehatan. Sejak zaman dahulu masyarakat Indonesia telah menggunakan obat bahan alam untuk beberapa tujuan, diantaranya mencegah penyakit, meningkatkan daya tahan tubuh, meningkatkan kebugaran, Dan untuk menjadikan tanaman sebagai bahan produk kecantikan wanita (Uji Keamananekstrak Etanol Daun Mindi(, n.d.).

Sampai saat ini penggunaan obat-obat tradisional masih sangat digemari oleh sebagian besar masyarakat Indonesia, mereka menggangap bahwa penggunaan obat tradisonal lebih aman dari obat-obatan yang ada di apotek dan harganya juga jauh lebih murah serta terjangkau. Obat tradisional juga obat yang gampang ditemui di lingkungan masyarakat. Bersumber pada studi tanaman obat serta jamu tahun 2001, Indonesia memiliki sumber alam biologi terdiri dari 2. 848 spesies tanaman obat dengan 32.014 racikan obat, serta sudah digunakan secara turun- temurun guna mengobati berbagai macam sakit penyakit.

Menurut World Health Organizing (WHO), sekitar $80 \%$ penduduk di negara berkembang dan sekitar $65 \%$ penduduk yang berada di negara maju lebih memilih untuk menggunakan obat tradisional. meningkatnya penggunaan obat tradisional juga dipengaruhi dengan adanya anggapan dari sebagian besar masyarakat, bahwa efek samping menggunakan obat tradisonal lebih minim atau sedikit dibandingkan dengan obat-obat sintetis. Berdasarkan Data dari sekretariat Convention on Biological Diversity

(CBD) menunjukkan bahwa angka penjualan obat tradisional secara menyeluruh, mencapai angka 60 miliar dollar AS setiap tahunnya. Berdasarkan definisinya obat tradisional merupakan obat dengan bahan atau ramuan bahan yang ditemui di tumbuhan, hewan, bahan mineral, sediaan sarian (galenik) atau campuran dari bahan tersebut yang sudah digunakan secara turun temurun (Parwata, 2012).

$\begin{array}{lrr}\text { Menurut } & \text { KEMENKES } & \text { RI } \\ \text { No.1076/Menkes/SK/VII/2003 } & \text { yaitu }\end{array}$ Tentang penyediaan dan penggunaan obat tradisional, disebutkan pada dasarnya pengobatan tradisional adalah salah satu upaya pengobatan yang dilakukan diluar ilmu kedokteran maupun ilmu keperawatan dimana sudah banyak masyarakat memanfaatkan pengobatan tradisional ini untuk mengatasi berbagai macam masalah kesehatan yang terjadi. Berdasarkan cirinya bahan baku obat tradisional sendiri masih berupa simplisia dimana masih banyak bahan baku yang belum dilakukan standarisasi dan diteliti. Dan Bentuk penyajiannya pun masih sangat umum dan sederhana berupa serbuk, pil, seduhan/rebusan atau rajangan simplisia, dan khasiatnya masih berdasarkan data empiris. Obat tradisional sendiri dibagai kedalam tiga jenis yaitu: jamu, obat herbal terstandar dan fitofarmaka (Syafi'i, 2019).

World Health Organization (WHO) menjabarkan arti dari pengobatan sendiri yaitu metode pengobatan dengan obat herbal,modern,dan tradisional oleh individu dalam mengatasi gejala penyakit yang dapat dikenali (Joru, 2019). Berdasarkan BPOM tahun 2016 dari hasil data riset Suryawati, didapati bahwa skor pengetahuan pada masyarakat Indonesia dalam penggunaan obat tradisional adalah 3,5 - 
6,3 dari skala 0 - 10. Data tersebut menunjukkan dari dasar pengetahuan masyarakat Indonesia dalam menggunakan obat tradisional masih tergolong rendah hingga sedang (Asnasari, 2017).

Masyarakat Sulawesi Utara yang ada dan menetap di daerah kawasan perhutanan juga telah banyak menggunakan sumber daya hutan terlebih khusus tumbuhan di sekitar tempat tinggalnya guna memenuhi kebutuhan hidupnya seperti kebutuhan pokok yaitu pangan, bahan konstruksi rumah, dan lainnya begitu juga dengan obat-obatan tradisional dan sejenisnya yang sudah dikenal sejak zaman purba di tanah Minahasa. Pengetahuan mengenai obat tradisional ini seringkali diturunkan dari generasi ke generasi selanjutnya (Kinho et al., 2010). Adanya perkembangan zaman budaya yang pesat atau modernisasi budaya dapat mempengaruhi tingkat pengetahuan tradisional yang juga dimiliki oleh masyarakat setempat.

Dalam penggunaanya, obat tidak hanya diberikan kepada orang dewasa, tetapi diberikan juga kepada anak-anak. Pada dasarnya manusia memiliki lima fase yaitu dimulai dari fase bayi, anak-anak, remaja, hingga dewasa dan fase Tua Dari semua fase manusia fase anakanak adalah fase yang dianggap sangat mudah terkena penyakit apalagi di usia Balita. Berdasarkan hasil Susenas kor tahun 2015 data kesehatan menurut kelompok umur anak presentase anak yang mempunyai keluhan kesehatan cenderung turun seiring bertambahnya usia. Anak usia 0-4 tahun presentase mengalami keluhan kesehatan cenderung tinggi yaitu $42,65 \%$ hal itu disebabkan karena kondisi tubuh anak yang masih rentan (Kemenppa RI, 2018) Dalam mengkonsumsi obat, anak perlu pendampingan dari orangtua. DEPKES menyatakan secara fisiologis pada anak, ada beberapa organ penting yang belum berfungsi penuh seperti pada orang dewasa. Hal ini akan mempengaruhi proses farmakokinetikfarmakodinamik obat. Pertumbuhan dan perkembangan organ-organ tubuh pada anak akan mempengaruhi efektivitas serta toksisitas obat. Salah satu pengobatan tradisional atau nonfarmakologi yang dilakukan kepada anak adalah dengan kompres bawang merah saat anak demam, terbukti pada penelitian yang dilakukan oleh Etika Dewi dimana terdapat perbedaan suhu saat sebelum dan sesudah dilakukanya kompres bawang merah yaitu $0.734{ }^{\circ} \mathrm{C}$ dengan nilai signifikan $0,000<0,005$ yang artinya ada perbedaan suhu tubuh yang signifikan sebelum dan sesudah kompres bawang merah pada anak (D. \& P. D. Cahyaningrum, 2017).

Berdasarkan WHO yang dikategorikan sebagai anak ialah mereka yang ada sejak dalam kandungan hingga dengan usia 19 tahun. Menurut UU RI No.23 Tahun 2002 pasal 1 ayat 1 anak adalah seseorang yang usianya belum menginjak 18 tahun. Untuk menentukan dosis obat pada anak seringkali ditemukan adanya kesulitan-kesulitan, terutama pada bayi usia prematur, bayi baru lahir, dan masih balita karena adanya organ-organ yang memang fungsinya belum sempurna, antara lain hati, ginjal dan susunan saraf pusat. Terdapat juga perbedaan distribusi cairan tubuh pada anak dengan orang dewasa karena cairan tubuh pada anak secara presentase berat badan lebih besar, serta terdapat perbedaan pola absorbsi, distribusi, metabolisme, eksresi (ADME) antara anak-anak dan dewasa (Ketut, 2016). Orangtua harus memiliki pengetahuan yang cukup dalam memberikan obat terhadap anak 
yang dilakukan langsung oleh orangtua, agar terhindar dari kesalahan selama pemberian obat berlangsung.

Pengetahuan merupakan hasil dari rasa ingintahu melalui berbagai proses baik secara sensoris, yaitu pada mata dan telinga terhadap objek tertentu, pengetahuan juga merupakan suatu penilaian yang penting dalam proses terbentuknya perilaku yang terbuka atau open behavior, Pengetahuan tradisional sendiri merupakan unsur budaya yang muncul berdasarkan pengalaman individu karena adanya suatu interaksi dengan lingkunngan (Ani et al., 2018).

Menurut Efendi dan Makhfudli dalam (Eirene, 2017) Pengetahuan memiliki 6 tingkatan yaitu: 1)Tahu (know) yang diartikan sebagai recall atau mengingat kembali sesuatu yang telah dipelajari dan diterima dari sebelumnya; 2) Memahami (comprehension) yang artinya kemampuan untuk menjelaskan dan juga menginterpretasikan materi yang diketahui secara benar; 3) ]Aplikasi (application) yaitu kemampuan individu dalam menggunakan atau mengaplikasikan prinsip pada situasi dan kondisi yang sebenarnya; 4)Analisis (analysis) yaitu kemampuan individu dalam menjabarkan materi atau objek tertentu dalam komponen-komponen yang ada di suatu masalah yang berkaitan satu sama lain; 5)Sintesis (synthesis) yaitu kemampuan individu dalam meletakkan atau menghubungkan suatu bagian objek tertentu ke dalam bentuk keseluruhan yang baru; 6)Evaluasi (evaluation) yang merupakan kemampuan individu dalam melakukan penilaian untuk suatu materi dan objek tertentu.

$\begin{array}{lll}\text { Menurut Nursalam } & \text { dalam } \\ \text { (Kusumawardani et al., } & \text { 2012) }\end{array}$

menjelaskan pengetahuan individu bisa dinilai melalui skala kualitatif sebagai berikut: pengetahuan baik 76\%-100\%, pengetahuan cukup $56 \%-75 \%$, dan pengetahuan kurang $<56 \%$. Dari Hasil penelitian (Syofyan et al., 2019) menjelaskan bahwa pengetahuan orangtua dalam menggunakan obat tradisional sebagai media pengobatan pada anak mereka sangat dibutuhkan agar tidak terjadi kesalahan dalam pemberian obat sehingga tidak memperlambat proses penyembuhan dan lamanya waktu penyembuhan terhadap penyakit anak.

Sedangkan sikap merupakan suatu derajat afek yang bersifat positif dan negatif dari objek psikologis (Pengantar, 2014). Sikap Juga merupakan salah satu tindakan yang masih tertutup,tidak bisa dilihat secara langsung. Sikap itu sendiri ada tiga yaitu ; 1) Kepercayaan atau ide dan konsep dari objek, yaitu bagaimana keyakinan serta pendapat atau polapikir individu terhadap objek ; 2) Kehidupan emosional yang merupakan evaluasi individu terhadap objek; 3) Kecenderungan untuk melakukan sesuatu atau bertindak, dimana sikap adalah bagian komponen yang mendahului tindakan maupun perilaku yang terbuka (Nurul, 2013).

Berdasarkan hasil pengamatan yang peneliti lakukan, masih banyak orangtua yang tinggal di Desa Karegesan melakukan pengobatan terhadap anak mereka yang sakit dengan menggunakan metode pengobatan tradisional yang mereka buat sendiri baik atas dasar pengetahuan pribadi maupun berdasarkan resep secara turuntemurun dari keluarga. Berdasarkan penelitian (Ismiyana et al., 2013) obat tradisional dalam pengolahanya bermacam macam dari yang dilakukan 
dengan cara sederhana misalkan direbus, dipipis bahkan diseduh hingga menggunakan teknologi yang maju berupa kemasan. Berdasarkan uraian diatas peneliti sangat perlu melakukan penelitian mengenai Tingkat pengetahuan dan sikap orangtua berhubungan dengan penggunaan obat tradisional pada anak yang dilakukan di desa Karegesan, Kecamatan Kauditan, Sulawesi Utara. Adapun tujuan dilakukanya penelitian ini ialah untuk mengetahui apakah ada hubungan yang signifikan dari tingkat pengetahuan serta sikap orangtua yang berada di desa karegesan dalam menggunakan obat tradisional untuk pengobatan pada anak.

\section{METODE}

Penelitian ini merupakan jenis penelitian deskriptif korelasi. Populasi untuk penelitian ini yaitu orangtua (ayah atau ibu) yang memiliki anak yang berusia antara 1-12 tahun yang tinggal di Desa Karegesan, Kecamatan kauditan, Sulawesi Utara. Teknik yang digunakan untuk menentukan sampel, adalah teknik purposive sampling yaitu teknik untuk menentukan sampel penelitian dengan beberapa pertimbangan tertentu dengan kriteria inklusi sebagai berikut: 1) Subjek penelitian laki-laki atau perempuan yang sudah menikah berdomisili di Desa Karegesan, Kecamatan Kauditan, Sulawesi Utara ; 2) Memiliki anak dengan rentang usia 1-12 tahun ; 3) Bersedia untuk ikut pada penelitian ini secara sukarela, yang ditandai dengan mengisi formulir informed consent. Sedangkan kriteria eksklusi subjek penelitian adalah: 1) Subjek yang memiliki hambatan dalam berkomunikasi ; 2) Berdomisili di luar Desa Karegesan, Kecamatan Kauditan, Sulawesi Utara ; 3) Tidak bersedia untuk menjadi responden. Kriteria tersebut ditentukan agar data yang diperoleh lebih representatif (Saputra, 2019).

Penelitian ini dilakukan secara online, yaitu peneliti mengirimkan kuesioner dalam bentuk googleform kepada responden melalui aplikasi whatsapp. Sebelum mengisi kuesioner, responden terlebih dahulu mengisi informed consent yang menyatakan bahwa responden bersedia untuk berpartisipasi di penelitian ini tanpa paksaan. Penelitian ini menggunakan Instrumen berupa kuesioner pengetahuan dan sikap yang di adopsi dari penelitian (Joru, 2019) yang berisi pertanyaan tentang pengetahuan responden mengenai obat tradisional terdiri dari definisi obat tradisional, bentuk sediaan obat tradisional, pengelompokkan dan kemasan obat tradisional. Kuesioner ini menggunakan skala Guttman yang merupakan skala dengan jawaban tegas, sebagai skala pengukuran dengan jawaban yang di dapatkan yaitu, benar, salah dan tidak tahu. Untuk mengetahui sikap responden dalam pemilihan obat tradisional dengan skala likert yaitu dengan jawaban sangat setuju nilainya 5, jawaban setuju diberi 4, jawaban netral nilainya 3 , jawaban tidak setuju nilainya 2 dan jawaban sangat tidak setuju nilainya 1 .

Kedua bagian kuesioner ini telah diuji validitas serta reabilitas dengan hasil masing masing untuk pengetahuan nilai Chronbach Alpha 0.226 lebih besar dari 0.05 dan nilai untuk sikap 0.7 lebih dari 0.05 dari hasil tersebut maka kedua kuesioner reliabel. Peneliti menganalisa data yang terkumpul menggunakan SPSS versi 20 dan untuk mengukur hubugan antara pengetahuan (variabel x) dan sikap orangtua (variabel y) menggunakan uji korelasi pearson correlation. Penelitian ini telah lulus uji etik dari Komite Etik Penelitian 
Kesehatan Fakultas Ilmu Keperawatan Universitas Advent Indonesia, dengan surat No 209/EKS-SU/XI/20 dan sudah mendapat izin dari Kepala Desa Karegesan.

\section{HASIL}

Responden yang terlibat berjumlah 52 orang. Semua responden dapat mengisi kuesioner yang diberikan secara lengkap sehingga tidak ada yang perlu dieliminasi.

Tabel 1.

Karakteristik Responden $(\mathrm{n}=52)$

\begin{tabular}{lcc}
\hline \multicolumn{1}{c}{ Karakteristik } & $\mathrm{f}$ & $\%$ \\
\hline Jenis kelamin & & \\
Perempuan & 46 & 88,5 \\
Laki-laki & 6 & 11,5 \\
\hline Usia & & \\
$17-25$ & 12 & 23,1 \\
$26-35$ & 20 & 38,5 \\
$36-45$ & 16 & 30,8 \\
$46-55$ & 4 & 7,7 \\
\hline Jumlah anak & & \\
1 & 19 & 36,5 \\
2 & 17 & 32,7 \\
3 & 13 & 25,0 \\
4 & 3 & 5,8 \\
\hline
\end{tabular}

Tabel 2.

Pola Penggunaan Obat $(n=52)$

\begin{tabular}{lcc}
\hline \multicolumn{1}{c}{ Karakteristrik } & $\mathrm{f}$ & $\%$ \\
\hline Frekuensi & & \\
1x sebulan & 13 & 25,0 \\
2x sebulan & 7 & 13,5 \\
3x sebulan & 4 & 7,7 \\
4x sebulan & 9 & 17,3 \\
Lainya & 19 & 36,5 \\
\hline Keluhan Sakit & & \\
Demam & 28 & 53,8 \\
Diare & 10 & 19,2 \\
Maag & 1 & 1,9 \\
Lainya & 13 & 25,0 \\
\hline Obat yang digunakan & & \\
Antangin JRG & 3 & 5,8 \\
Tolak angin & 9 & 17,3 \\
Diapet & 5 & 9,6 \\
Lelap & 1 & 1,9 \\
Lainnya & 34 & 65,4 \\
\hline Efek samping & & 69,2 \\
Tidak ada & 36 & 30,8 \\
Mengantuk & 16 & \\
\hline
\end{tabular}


Tabel 3

Tingkat Pengetahuan Orangtua $(n=52)$

\begin{tabular}{lcc}
\hline \multicolumn{1}{c}{ Karakteristrik } & $\mathrm{f}$ & $\%$ \\
\hline Frekuensi & & \\
Baik & 19 & 36,5 \\
Cukup & 6 & 11,5 \\
Kurang & 27 & 52,0 \\
& Rata-rata & 53,08 \\
\hline
\end{tabular}

Tabel 4.

Sikap Orangtua $(\mathrm{n}=52)$

\begin{tabular}{lcc}
\hline \multicolumn{1}{r}{ Karakteristrik } & $\mathrm{f}$ & $\%$ \\
\hline Sikap & & \\
Baik & 19 & 36,5 \\
Cukup & 9 & 17,3 \\
Kurang & 24 & 46,2 \\
& Rata-rata & 17,3 \\
\hline
\end{tabular}

Tabel 1, dari 52 orang responden yang bersedia untuk berpartisipasi dalam penelitian ini, mayoritas berjenis kelamin perempuan sekitar 46 orang $(88,5 \%)$. Berdasarkan karakteristik usia, responden ada di rentang usia 2635 tahun yaitu sebanyak 20 orang $(38,5 \%)$, Dari karakteristik jumlah anak mayoritas Responden memiliki 1 orang anak yaitu 19 responden $(36,5 \%)$.

Tabel 2, frekuensi penggunaan obat lebih dari $1 \mathrm{x}$ dalam jangka waktu sebulan sebanyak 25,0\% atau sekitar 13 orang. Keluhan sakit yang paling dominan yaitu demam sebanyak 53,8\% sekitar 28 orang. Obat yang sering di gunakan saat sakit yaitu responden memilih opsi lainya dengan presentase sebanyak $65,4 \%$ atau sekitar 34 orang, selain itu 9 orang atau $17,3 \%$ memilih menggunakan tolak angin dan 5 orang sebanyak 9,6\% menggunakan diapet. Dan sebanyak 36 responden tidak ada keluhan atau efek samping yang terjadi saat menggunakan obat tradisional.
Tabel 3, menunjukan bahwa Tingkat pengetahuan orangtua berhubungan dengan penggunaan obat tradisional pada anak, yaitu 52\% (27 orang) berada pada kategori kurang, pengetahuan cukup sebesar $11,5 \%$ (6 orang), dan untuk kategori baik berjumlah 17,3\% (19) orang.

Tabel 4, presentase sikap yang kurang terhadap pola pengobatan pada anak dengan obat tradisional yaitu sekitar $46,2 \%$ (24 orang), dan sikap cukup dengan presentase $17,3 \%$ (9 orang), sikap baik sekitar 36,5\% (19 orang). Untuk mengetahui apakah ada hubungan yang signifikan dari tingkat pengetahuan serta sikap orangtua yang berada di desa karegesan dalam menggunakan obat tradisional untuk pengobatan pada anak di desa karegesan, maka dilakukan uji korelasi dengan menggunakan uji pearson correlation yang ada pada tabel 5 berikut ini. 
Tabel 5.

Uji Korelasi Pearson $(\mathrm{n}=2)$

\begin{tabular}{llcc}
\hline & & Total X & Total Y \\
\hline \multirow{2}{*}{ Total X } & Pearson Correlation Sig. (2- & 1 & $.501^{* *}$ \\
& tailed) & &, 000 \\
& $\mathrm{~N}$ & 52 & 52 \\
\hline \multirow{2}{*}{ Total Y } & Pearson Correlation & $.501^{* *}$ & 1 \\
& Sig. (2-tailed) &, 000 & 52 \\
& $\mathrm{~N}$ & 52 & \\
\hline
\end{tabular}

Berdasarkan hasil analisa data pada tabel 5 dengan menggunakan uji statistik pearson correlation didapati hasil bahwa Adanya hubungan yang signifikan dari pengetahuan yang kurang baik dengan sikap orangtua yang kurang baik dalam menggunakan obat tradisional untuk pengobatan pada anak dengan $p$ value $0,000<0,05$. Hal ini mengartikan bahwa pengetahuan yang dimiliki orangtua mempunyai hubungan dengan sikap yang dimiliki orangtua tersebut.

\section{PEMBAHASAN}

\section{Karakteristik Responden}

Berdasarkan karakteristik usia responden berusia 26-35 tahun sebanyak 20 orang atau sekitar 38,5\%. Menurut (Putri, 2018) menyatakan bahwa individu yang tergolong dewasa awal mereka yang usianya 20-40 tahun mereka memiliki peran dan tugas yang tentu saja semakin besar individu juga tidak harus selalu bergantung kepada orangtua baik secara ekonomis, sosiologis maupun fisiologis. Dan responden penelitian ini berjenis mayoritas berjenis kelamin perempuan sebanyak 46 orang sekitar $88,5 \%$. Ini dikarenakan perempuan cenderung lebih peduli dengan kesehatan, Didukung oleh (Sunardi \& Sri Sumartini, 2018) yang menyatakan bahwa Wanita lebih peka dan peduli kesehatan dan cenderung mempunyai pengetahuan yang lebih baik dibandingkan dengan laki-laki. Dan rata-rata responden hanya memiliki 1 anak 19 responden sekitar 36,5\%. Mungkin dikarenakan berbagai latar belakang keluarga salah satunya orangtua berfikir akan terjadi perselisihan atau kecemburuan antara anak pertama dan anak berikutnya atau bahkan ketika orangtua memiliki anak kembar yang disebut dengan Sibling Rivalry yaitu sebuah perasaan yang tidak nyaman pada anak yang akan membuat anak merasa seperti sedang berkompetisi sehingga membuat kecenderungan orangtua akan memihak pada satu anak saja (Marpaung, 2015)

\section{Karakteristik Pola penggunaan obat}

Berdasarkan pola penggunaan obat dengan frekuensi $1 \mathrm{x}$ dalam jangka waktu sebulan sebanyak 13 orang yaitu sekitar 25,0\%. Berdasarkan penelitian (Asnasari, 2017) digunakan batasan rentang waktu satu bulan terakhir dengan tujuan untuk mempermudah responden mengingat obat yang digunakan dan untuk menghindari bias. Keluhan sakit yang sering dialami anakanak adalah demam, sebanyak 28 anak atau sekitar 53,8\% anak di desa karegesan keluhan sakit yang sering dialami adalah demam. Demam juga merupakan adanya reaksi dari tubuh ketika tubuh terinfeksi baik oleh virus maupun bakteri dan patogen lainya sehingga terjadilah peningkatan suhu tubuh (Rachmawati \& Kartika, 2020) Pada anak-anak dianggap demam bila temperatur rektal $38^{\circ} \mathrm{C}$ atau lebih tinggi 
dan temperatur oral lebih tinggi dari $37,6^{\circ} \mathrm{C}$ (D. \& P. D. Cahyaningrum, 2017). Obat yang diberikan oleh orangtua saat anak sakit sekitar 9 orang atau $17,3 \%$ menggunakan tolak angin, dimana tolak angin bermanfaat untuk menjaga stamina tubuh dan mengobati berbagai macam gejala penyakit yang terbilang masih ringan (Sahidin et al., 2019) Dan sebanyak 36 atau sekitar $69,2 \%$ responden mengklaim tidak adanya efek samping atau bahkan sangat minim dari obat yang telah di konsumsi oleh anak mereka (Elisma et al., 2020). Terbukti menurut (E. D. Cahyaningrum, 2016) efek samping obat tradisional terbukti minim atau sedikit dan bahkan tidak menimbulkan efek samping, itu dikarenakan terdapatnya bahan kimia dalam tanaman obat tradisional sebagian besar dapat dimetabolisme oleh tubuh.

\section{Karakteristik Tingkat Pengetahuan}

Berdasarkan tabel 3, menyatakan tingkat pengetahuan yang dimiliki oleh orangtua yang berada didesa karegesan dalam penggunaan obat tradisional kepada anak mereka masuk kedalam kategori kurang dimana 46,2\% atau 24 orang, yang masuk kedalam kategori pengetahuan kurang menurut (Pratomo \& Dewi, 2018) yaitu apabila presentase dibawah $<56 \%$. Pengetahuan yang kurang bisa saja disebabkan oleh faktor usia, dimana responden dalam penelitian ini masih masuk dalam kategori dewasa awal yang mungkin dalam kategori usia masih sangat awam dengan pengobatan tradisional. seperti yang disebutkan dengan bertambahnya usia seseorang bisa membawa pengaruh akan pertambahan pengetahuan serta berkembangnya pola pikir yang dimilikinya (Robiyanto et al., 2018).

\section{Karakteristik Sikap}

Berdasarkan tabel 4, didapati sikap yang dimiliki orangtua yang berada didesa karegesan dengan presentase 46,2\% atau 24 orang masuk ke dalam kategori kurang, Menurut (Villela, 2013) kategori sikap kurang yaitu dimana presentase dibawah $<56 \%$, menurut (Rahmayanti, 2011) faktor-faktor berikut ini dapat mempengaruhi pembentukan sikap seseorang yaitu antara lain ; pengaruh orang lain, pengalaman pribadi, kebudayaan, dan media massa serta faktor emosional. oleh sebab itu sesuai dengan hasil penelitian yang didapatkan peneliti mengambil kesimpulan bahwa tingkat pengetahuan mempengaruhi sikap orangtua. Jika tingkat pengetahuan dalam kategori baik maka sikap yang dihasilkan juga baik, dan sebaliknya. Sikap aspek positif yang dimiliki oleh individu bisa dipengaruhi oleh pengetahuan yang positif juga, dan sebaliknya (Fuadi, 2016).

Berdasarkan hasil analisis diatas peneliti melakukan uji korelasi dengan menggunakan uji pearson correlation dan didapati hasil Adanya hubungan yang signifikan dari pengetahuan yang kurang baik dengan sikap orangtua yang kurang baik dalam menggunakan obat tradisional untuk pengobatan pada anak dengan $p$ value $0,000<0,05$. Hal ini mengartikan bahwa pengetahuan yang orangtua miliki mempunyai hubungan dengan sikap yang dimiliki orangtua tersebut. Menurut Notoatmodjo dalam (Joru, 2019) bahwa seseorang itu akan bersikap atau berperilaku berdasarkan beberapa pertimbangan yang diperoleh seseorang tersebut dari tingkat pengetahuanya. 


\section{SIMPULAN}

Setelah dilakukan Uji Pearson Correlation dengan hasil Adanya hubungan yang signifikan dari pengetahuan yang kurang baik dengan sikap orangtua yang kurang baik dalam menggunakan obat tradisional untuk pengobatan pada anak dengan $p$ value $0,000<0,05$. Dimana ada 24 orangtua dengan presentase $46,2 \%$ memiliki pengetahuan dan sikap dengan kategori kurang atau dibawah $<56 \%$.

\section{DAFTAR PUSTAKA}

Ani, N., Rohyani, I. S., \& Ustadz, M. (2018). Pengetahuan Masyarakat Tentang Jenis Tumbuhan Obat Di Kawasan Taman Wisata Alam Madapangga Sumbawa. Jurnal Pijar Mipa, 13(2), 160. https://doi.org/10.29303/jpm.v13i 2.751

Asnasari, L. (2017). Hubungan Pengetahuan Tentang Swamedikasi Dengan Pola Penggunaan Obat Pada Masyarakat Dusun Kenaran, Sumberharjo, Prambanan, Sleman, Yogyakarta. Skripsi, 154.

https://repository.usd.ac.id/16343/ 2/148114031_full.pdf

Cahyaningrum, D. \& P. D. (2017). Perbedaan Suhu Tubuh Anak Demam Sebelum Dan Setelah Kompres Bawang Merah Etika Dewi Cahyaningrum 1, Diannike Putri 1 1. Perbedaan Suhu Tubuh Anak Demam Sebelum Dan Setelah Kompres Bawang Merah, 15(2), 66-74.

Cahyaningrum, E. D. (2016). Penatalaksanaan anak demam oleh orang tua di puskesmas kembaran I banyumas. Viva Medika, 09(17), 44-53. https://ejournal.uhb.ac.id/index.ph $\mathrm{p} / \mathrm{VM} /$ article/view/127

Eirene. (2017). Pengaruh Edukasi dengan Metode Peer Group terhadap Pengetahuan dan Sikap anak SD tentang Personal Hygiene. Journal of Chemical Information and Modeli, 53(9), 1689-1699.

Elisma, E., Rahman, H., \& Lestari, U. (2020). Ppm Pemberdayaan Masyarakat Dalam Pengolahan Tanaman Obat Sebagai Obat Tradisional Di Desa Mendalo Indah Jambi Luar Kota. SELAPARANG Jurnal Pengabdian Masyarakat Berkemajuan, 4(1), 274. https://doi.org/10.31764/jpmb.v4i 1.2736

Fuadi, F. I. (2016). Hubungan Antara Pengetahuan dengan Sikap Masyarakat dalam Mencegah Leptospirosis di Desa Pabelan Kecamatan Kartasura Kabupaten Sukoharjo. Promosi Kesehatan Dan Perilaku Kesehatan., 1-17.

Ismiyana, F., Rahman Hakim, A., \& Sujono, T. A. (2013). Gambaran Penggunaan Obat Tradisional Untuk Pengobatan Sendiri Pada Masyarakat Di Desa Jimus Polanharjo Klaten.

Joru, E. (2019). hubungan pengetahuan dan sikap terhadap pola penggunaan obat tradisional untuk pengobatan mandiri dikalangan mahasiswa kampus III universitas sanata dharma yogyakarta. Skripsi Kefarmasian Universitas Sanata Dharma Yogyakarta. http://repository.usd.ac.id/34038/2 /148114027_full.pdf

Kemenppa RI. (2018). Profil Kesehatan 
Anak Indonesia Tahun 2018. Ilmu Pendidikan, 5(1), 12-21.

Ketut, B. (2016). Menentukan Dosis Obat Dan Cara Pemberiannya.

Kinho, J., Arini, D. I. D., Halidah, Nurrani, L., \& Halawane, J. E. (2010). Domestikasi Tumbuhan Obat Tradisional di Provinsi Sulawesi Utara.

Kusumawardani, E., Arkhaesi, N., \& Hardian, H. (2012). Pengaruh Penyuluhan Kesehatan Terhadap Tingkat Pengetahuan, Sikap Dan Praktik Ibu Dalam Pencegahan Demam Berdarah Dengue Pada Anak. Jurnal Kedokteran Diponegoro, 1(1), 104456.

Marpaung, R. F. (2015). Sibling Rivalry pada Anak Kembar. Universitas Medan Area, 1(1), 7-12.

Nurul, mas'ud waqiah. (2013). persepsi masyarakat. Persepsi Masyarakat Terhadap Perawatan Ortodontik Yang Dilakukan Oleh Pihak Non Profesional, 53(9), 1689-1699.

Oktarlina, R. Z., Tarigan, A., Carolia, N., \& Utami, E. R. (2018). Hubungan Pengetahuan Keluarga dengan Penggunaan Obat Tradisional di Desa Nunggalrejo Kecamatan Punggur Kabupaten Lampung Tengah. JK Unila, 2(1), 42-46.

Parwata, I. M. O. A. (2012). Obat Tradisional. Jurnal Keperawatan Universitas Jambi, 1-69.

Pengantar, K. (2014). Pengaruh Pengetahuan Dan Sikap Orang Tua Terhadap Swamedikasi Obat Demam Pada Anak-Anak. Media Farmasi, 11(2), 221-231. https://doi.org/10.12928/mf.v11i2.

\section{1}

Pratomo, G. S., \& Dewi, N. A. (2018). Tingkat Pengetahuan Masyarakat Desa Anjir Mambulau Tengah terhadap Penggunaan Antibiotik. Jurnal Surya Medika, 4(1), 79-89. https://doi.org/10.33084/jsm.v4i1. 354

Putri, A. F. (2018). Pentingnya Orang Dewasa Awal Menyelesaikan Tugas Perkembangannya. SCHOULID: Indonesian Journal of School Counseling, 3(2), 35. https://doi.org/10.23916/0843001 1

Rachmawati, A., \& Kartika, L. (2020). Pengetahuan Ibu dan Pengelolaan Demam Anak di Satu Rumah Sakit Swasta di Indonesia Barat. Jurnal Keperawatan Raflesia, 2(1), 11-20. https://doi.org/10.33088/jkr.v2i1.5 06

Rahmayanti, K. A. (2011). Hubungan Sikap Ibu Tentang Asi Eksklusif Dengan Perilaku Pemberian Asi Eksklusif Di Desa Sendangrejo Kecamatan Tayu Kabupaten Pati. 7-35.

http://digilib.unimus.ac.id/files/dis k1/121/jtptunimus-gdl-kikaaldela6006-2-babii.pdf

Robiyanto, R., Rosmimi, M., \& Untari, E. K. (2018). Analisis Pengaruh Tingkat Pengetahuan Masyarakat Terhadap Tindakan Swamedikasi Diare Akut Di Kecamatan Pontianak Timur. Edukasi: Jurnal Pendidikan, 16(1), 135. https://doi.org/10.31571/edukasi.v $16 \mathrm{i} 1.845$

Sahidin, S., Wahyuni, W., Kamaluddin, M., \& Suaib, S. (2019). Tanaman Obat Keluarga (TOGA) dan 
Pemanfaatannya Sebagai Penunjang Kesehatan Masyarakat di Desa Sindangkasih. Pharmauho: Jurnal Farmasi, Sains, Dan Kesehatan, 4(2), 2-4. https://doi.org/10.33772/pharmau ho.v4i2.6276

Saputra, R. (2019). 済無No Title No Title. Journal of Chemical Information and Modeling, 53(9), 1689-1699.

Sunardi, \& Sri Sumartini. (2018). Tingkat Pengetahuan Siswa Kelas Xii Sekolah Menengah Kejuruan "Indonesia" Yogyakarta Terhadap Obat Tradisional. Jurnal Kefarmasian Akfarindo, 40-46. https://doi.org/10.37089/jofar.v0i0 .46

Syafi'i, I. (2019). Pemasaran Jamu Menggunakan Kemasan Praktis Siap Minum Dengan Branding Tren Masa Kini. Jurnal Pembelajaran Pemberdayaan Masyarakat (JP2M), 1(1), 35. https://doi.org/10.33474/jp2m.v1i

\subsection{6}

Syofyan, S., Indra, H., Suryati, S., \& Almahdy, A. (2019). Pengetahuan dan Sikap tentang Obat pada Orangtua Siswa SD di Kota Padang. Jurnal Sains Farmasi \& Klinis, 5(3), 212. https://doi.org/10.25077/jsfk.5.3.2 12-217.2018

Uji keamananekstrak etanol daun mindi(. (n.d.).

Villela, lucia maria aversa. (2013). Definisi pengetahuan. Journal of Chemical Information and Modeling, 53(9), 1689-1699.

Wisely. (2008). STUDI TENTANG Pemahaman Obat Tradisional Berdasarkan Informasi Pada Kemasan dan Alasan Pemilihan Jamu Ramuan Segar Atau Jamu Instan Pada Masyarakat Desa Maguwoharjo. Skripsi Kefarmasian Universitas Sanata Dharma Yogyakarta, 53(9). http://repository.usd.ac.id/17062/2 /058114111_Full.pdf 